\title{
危険の切迫に対して操船者が感じる危険感の定量化モデル
}

\author{
井上 欣三* ・ 久保野雅敬** \\ 宮坂 真人 $* * *$. 原 大地****
}

\section{Modeling of Mariners' Perception of Safety when Being Faced with Imminent Danger}

\author{
Kinzo INOUE, Masataka KUBONO, Makoto MIYASAKA and Daichi HARA
}

\begin{abstract}
In order to improve the marine traffic safety in narrow channels or inside ports and harbours, the judgement criteria must be established based on the mariners' perception of safety.

In the present paper, a quantitative expression model of the mariners' perception of safety is proposed. This model takes into account two kinds of perception of safety; one is against the structural obstacles and the other is against the encountering ships.

The extraction of mariners' senses was carried out by the simulator experiments and by the questionnaires. The difference of the senses between the pilots and the captains can be reflected in the model and the expression of senses of risk averse and risk preferable are also considered in the model.
\end{abstract}

\section{1.はじめに}

近年、東京湾横断道路、明石架橋、関西新空港など海上交通輻軑域での大規模海上構造物の建設や、ま た、国内主要港においては埋め立てによる港湾の沖合展開が著しく、これに伴って船舶は制約された水域 で困難な操船を余儀なくされる傾向が強くなっている。このように操船者を取り巻く周辺環境が大きく変 化しようとするとき、湾内、狭水道での海上交通ならびに港湾への出入操船の安全を確保するためには、 操船者の安全や危険に関する意識に基づく評価が不可欠となる。

井上らは、操船者と船を取り巻く環境下において、周辺環境が操船の困難さの面において課す負荷の程 度を、操船環境ストレス值と交通環境ストレス値を評洒指標として定量的に評価するための方法論を提案 している(1)(2)。

この評価モデルにおいては、操船環境ストレスの算定においても交通環境ストレスの算定においても、 操船者に課される負荷の大きさは、乗り揚げや衝突の危険が顕在化するまでの時間余裕を操船者が感じる 危険感に置き換えることにより定量化される。このとき、危険顕在化までの時間余裕を操船者が感じる危 険感に換算するにあたっては、広範な条件パラメータを含む、汎用性の高い、そして、信頼できる換算式 のモデル化が必要となる。

これに関し、原・田中は、開けた海域において操船者の地形に対する危険感を抽出することを目的に操 船シミュレータ実験を実施している(3)。この実験では被験者が数人に限られていたにもかかわらず、いくつ

* 正会員 神戸商船大学（广658-0022 神戸市東灘区深江南町5-1-1）

** 正会員 (侏ナビックスライン（テ100-8151 東京都千代田区一ツ橋1-1-1）

****正会員 (侏ナビックスライン（元100-8151 東京都千代田区一ツ橋1-1-1）

****正会員 (侏郵船海洋科学（元140-0004 東京都品川区南品川2-3-6） 
かの重要な知見を得ている。しかしながら、この結果が広く多くの操船者の意識を代表したものであるか どうかについては、更なる追試、検証が必要であるとの考えから、本研究では、ここでの実験方法を踏襲 しながら、あらためて操船シミュレータ実験を行うとともに、さらに、アンケート調査による広範なデー タ収集を試み、操船シミュレータ実験による意識抽出の結果とアンケートによる意識集約の結果の補完対 応関係の吟味を経た上で、多くの操船者の意識を反映した操船者の危険感の定量化モデルの策定を試みる ことにした。

\section{2. 護岸への乗り揚げに対する危険感の抽出}

\section{1 操船シミュレータ実験}

自船が港内水域において、一定針路、一定速力で護岸に直角に接近し、ついには乗り揚げるような状況 のシナリオをビジュアル操船シミュレータに再現し、複数の操船実務者がスクリーン上に投影された映像 を見ながら徐々に護岸に接近する過程でどのような危険を感じるかを回答する実験を実施した。

自船の初期位置は護岸の手前 2 マイルとし、評価地点は 0.1 マイルごとに設定した。ただし、交通要素や 外力要素の影響を受けない環境とするため、自船周囲には航行する他船はなく、無風、無潮流とした。回 答に際しては危険感を、+3 (非常に安全) +2 (かなり安全) +1 (やや安全)、0 (どちらともいえない)、1 (やや危険)、- -2 (かなり危険)、- -3 (非常に危険) の 7 段階に分類、記号化し、護岸に接近する過程で 評価地点を通過するごとに用紙に記入する方式をとった。

実験は神戸商船大学の操船シミュレータを用いて行い、被験者は水先人 10 名、外航船長 10 名、内航船長 11名の合計31名であった。なお、自船は船尾船橋型の一般貨物船とし、総トン数は、500GT、2,000GT、 3,500GT、8,000GT、55,000GTの 5 船型、速力は、4、6、8、10ノットの 4 種を組み合わせて実験ケー スを設定した。

2.2 アンケート調查

操船シミュレータで行った実験内容と同様の状況を、写真と図面と文章記述で説明したアンケート調查 用紙を作成し、これに対する回答を水先人と船長に郵送により依頼した。アンケート調查に際しては、回 答にあたり自分が操船する船は船尾船橋型の一般貨物船として、その船型区分は操船シミュレータ実験の 場合よりもさらに細かく設定した。

水先人へのアンケート調查に挍いては、自船船型は、300GT、1,000GT、5,000GT、10,000GT、17,000 GT、50,000GT、100,000GT、150,000GTの8 種類の船型とした。一方、船長用アンケートでは、回答に あたり自分が操船する船は、回答者のこれまでの操船経験をむとに各自が設定する方式をとった。回答者 が想定した船型は小型船から大型船まで広い範囲にわたっていたので、ここでは、想定された自船船型を 以下のような総トン数の範囲に分類した。そのグループ分類は、300〜600GT、600〜800GT、800〜2,000 GT、2,000 4,000GT、4,000 10,000GT、10,000 30,000GT、30,000GT以上の 7 種類である。

アンケート調查の実施にあたっては、日本パイロ ット協会、全国内航輸送海運組合、全国内航タンカ 一協会、大手外航船社の協力を得た。配布部数と回 収されたアンケート用紙の部数は、表 1 にとりまと めたとおりである。ここに、有効回答数として示し ているものは、各設間の記入事項に記入漏孔や誤解 等による不適切な記入があってデータとして取り扱 うことができないものを除外した件数である。

表 1 アンケートの配布と回収 (護岸への接近の危険感)

\begin{tabular}{|c|c|c|c|c|}
\hline 配布先 & 配布部数 & 回収部数 & 回収率 & 有効回答数 \\
\hline 水先人 & 632 通 & 125 通 & $19.8 \%$ & 112 通 \\
\cline { 1 - 2 } 内航船長 & 1865 通 & \multirow{2}{*}{638 通 } & $42.4 \%$ & 573 通 \\
\cline { 1 - 2 } 外航船長 & 140 通 & & & \\
\cline { 1 - 2 }
\end{tabular}

2.3 危険感に関する回答の集計

護岸までの距離が十分遠い範囲では被験者の回答は、十3 (非常に安全)の回答が連続し、護岸に接近す るにつれて+2 (かなり安全)、+1 (やや安全)、0 (どちらともいえない)、-1 (やや危険)、一 2 (かなり 危険) と変化し、そして、護岸までの距離が十分近い範囲になるとー3 (非常に危険) の回答が連続するよう になるのが一般的であった。そこで、実験ごとの被験者の回答のうち連続する＋3 や連続するー 3 のデー タを含むすべてのデータに着目するのではなく、一連の連続したデータのうち、最後の+ 3 から最初の一 

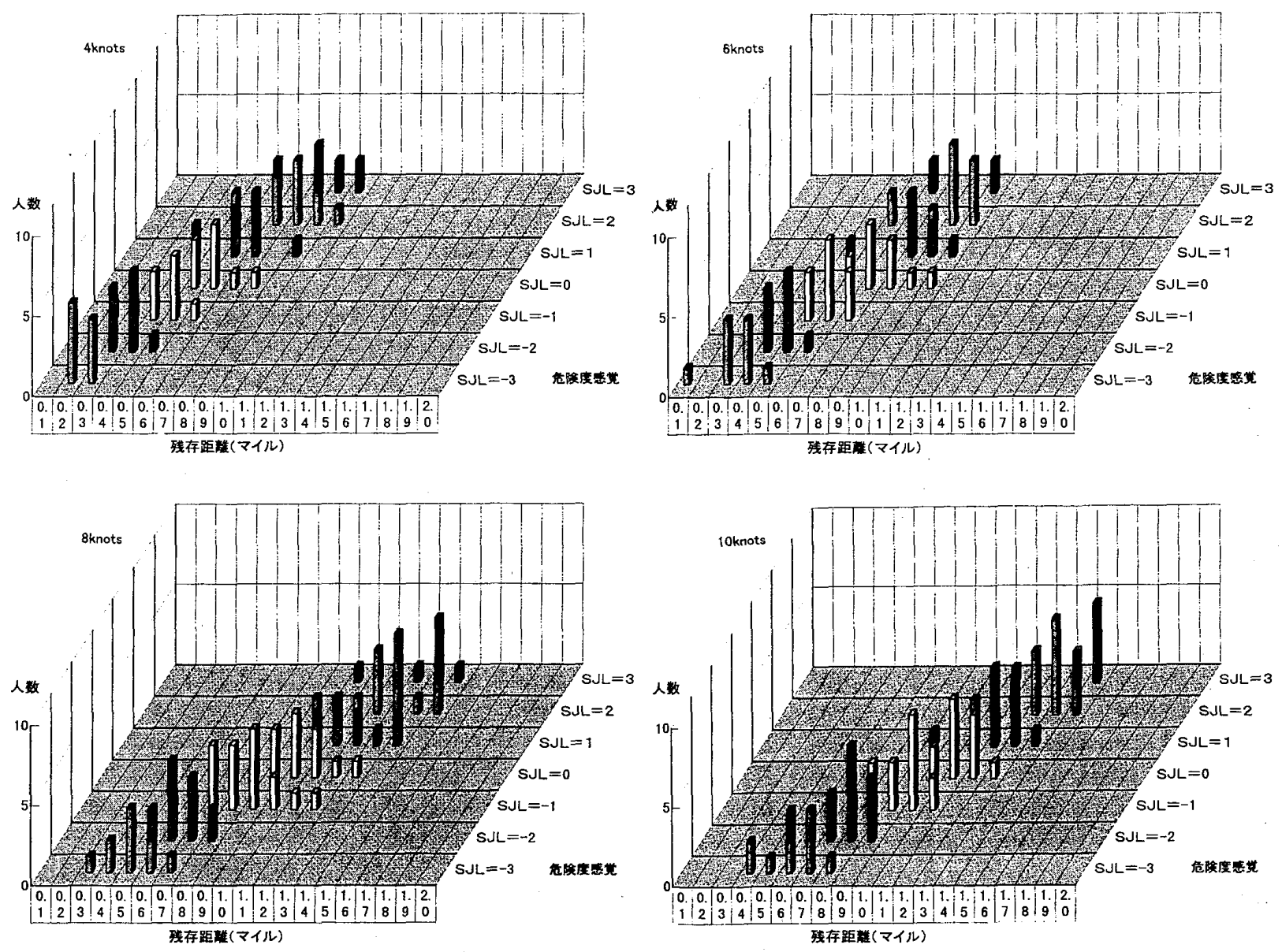

図 1 原データの散布図(水先人、自船8,000GT)

3 までのデータ群を対象に集計整理することとした。

図 1 は、操船シミュレータ実験において水先人を被験者としたときの、護岸までの残り距離とそのとき に感じる危険感に関する原データの散布図を例示している。図 1 は、8,000GTの船を自船とするときの例 示であるが、これをみてわかるように、残り距離が同じでも、自船速力が早いほど、操船者はより大きな 危険感を感じる様子がよく現れている。

次に、この原データをもとに、残り距離 $(R)$ を自船速力 $(V)$ で除して、護岸に乗り揚げるまでの余裕時間 $(R / V)$ とそのときに被験者が感じる危険感 $(S J L)$ の関係におきなおしてデータの散布図を求めた。原デー 夕を、護岸に乗り揚げるまでの余裕時間 $(R / V)$ を用いて整理した結果、自船速力の違いについては $(R / V)$ で基準化できることがわかった。そして、両者の間には直線近似の可能性が予想されたので、ここでは、 4、6、8、10ノットのそれぞれの自船速力のすべてのデータを重ねてプロットしたものに回帰直線をあ てはめて全体の傾向を整理することとした。しかし、自分が操船する船の大きさが異なると回㷌直線の勾 配が変化する傾向がうかがえた。そこで、回帰直線の勾配 $(\alpha)$ と縦軸切片 $(\beta)$ を「船型に応じて変化するパ ラメータ」として、

$$
\begin{aligned}
& S J L=\alpha(R / V)+\beta \\
& \alpha=f(\text { 自船船型 }) \\
& \beta=f \text { (自船船型 }) \\
& S J L: \text { 護岸への接近に対して操船者が感じる危険感 } \\
& R: \text { 護岸までの距離 } \\
& V: \text { 自船速力 } \\
& R / V: \text { 護岸に乗り揚げるまでの余裕時間 }
\end{aligned}
$$


の形のモデル式を策定することと した。ここに、 $\alpha$ と $\beta$ の值を自船 船型の関数として整理することに より、護岸への乗り揚げの危険が 顕在化するまでの時間余裕を操船 者が感じる危険感に置き換えるた めの変換式を得ることができる。

\section{4 回㷌分析}

操船シミュレータ実験から得ら れたデータも、アンケート調查を 通じて得られたデータも、また、 水先人から得たデータも、船長加 ら得たデータも、いずれも操船者 が感じる危険感のデータは類似の 変化傾向を示していたことから、 前述したようにすべて同じ手順で データを整理し集計を行ったうえ で回帰直線をあてはめた。

操船シミュレータ実験について の回帰分析の結果もアンケート調 查についての回帰分析の結果も、 どの場合もおおおむ秝 0.8 前後の良い 相関係数が得られた。

2.5 護岸への接近に対し操船者 が感じる危険感の定量化モ デルの策定

図2、図 3、図 4 は、回帰分析 の結果から得られた勾配 $(\alpha)$ と切 片 $(\beta)$ の值を自船船型 (総卜ン数) を横軸にとってプロットしたもの である。図 2 は、水先人のデータ に関する回帰分折から得られた勾 配 $(\alpha)$ と総卜ン数の関係、図 3 は、 船長のデータに関する回帰分析か ら得られた勾配 $(\alpha)$ と総トン数の 関係、図 4 は、切片 $(\beta)$ と総トン 数の関係を水先人の回帰分析の結 果と船長の回帰分析の結果を重和 てプロットしたものである。

ここに、図 2 に 2 重丸で、図 3 に二重三角で示したプロットは操 船シミュレータ実験から求めた回 帰直線の勾配を示している。これ らの図をみてわかるように、操船 シミュレータ実験による操船者の 意識の抽出結果とアンケート調查 による意識抽出の結果には大きな

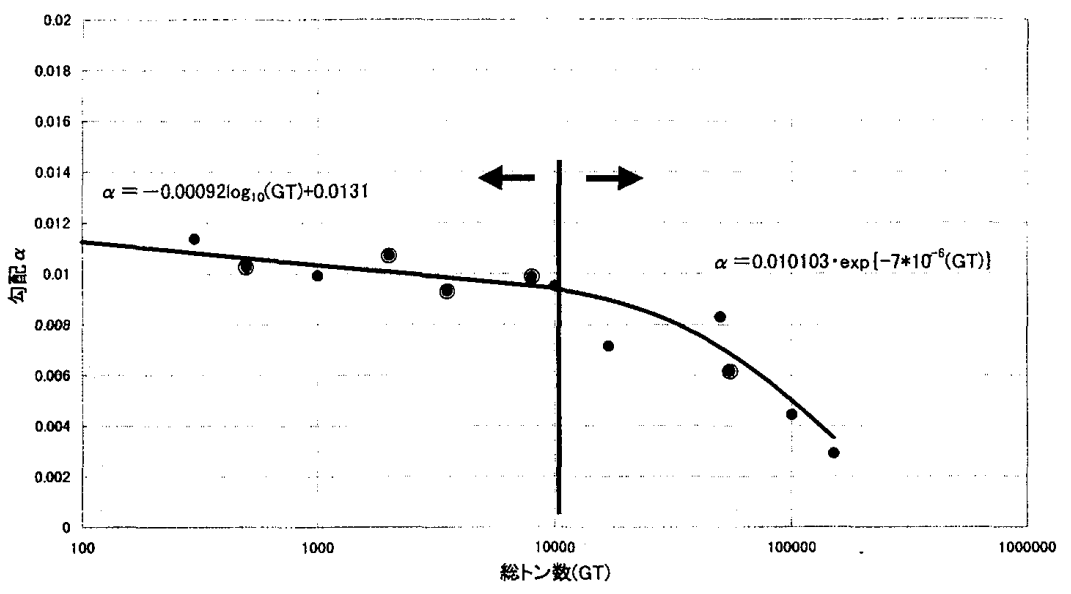

図 2 自船船型と勾配 $(\alpha)$ の関係(水先人) ※二重丸は操船シミュレータ実験

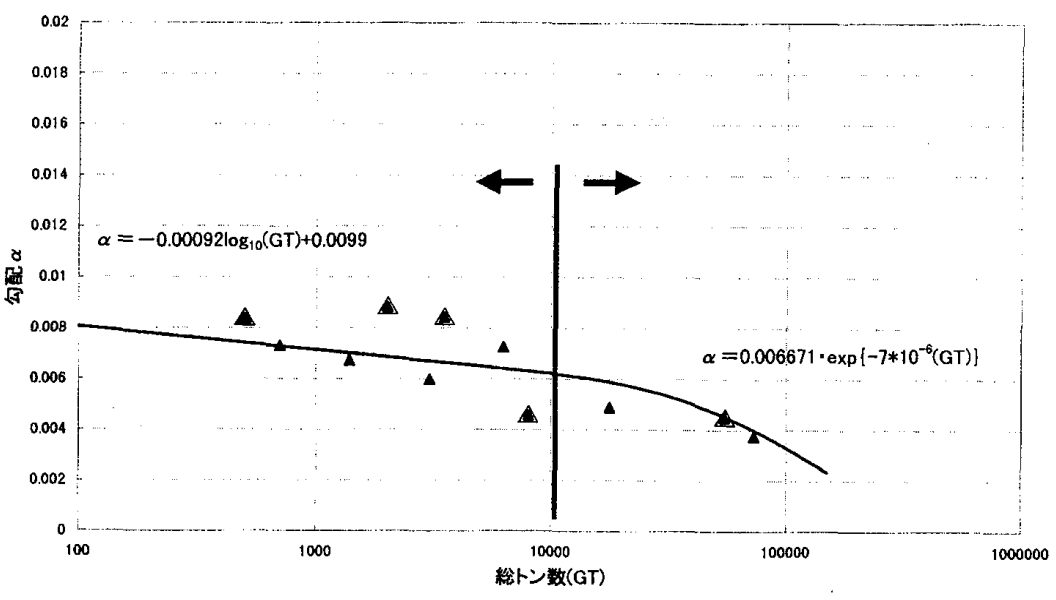

図 3 自船船型と勾配 $(\alpha)$ の関係(船長) ※二重三角は操船シミュレータ実験

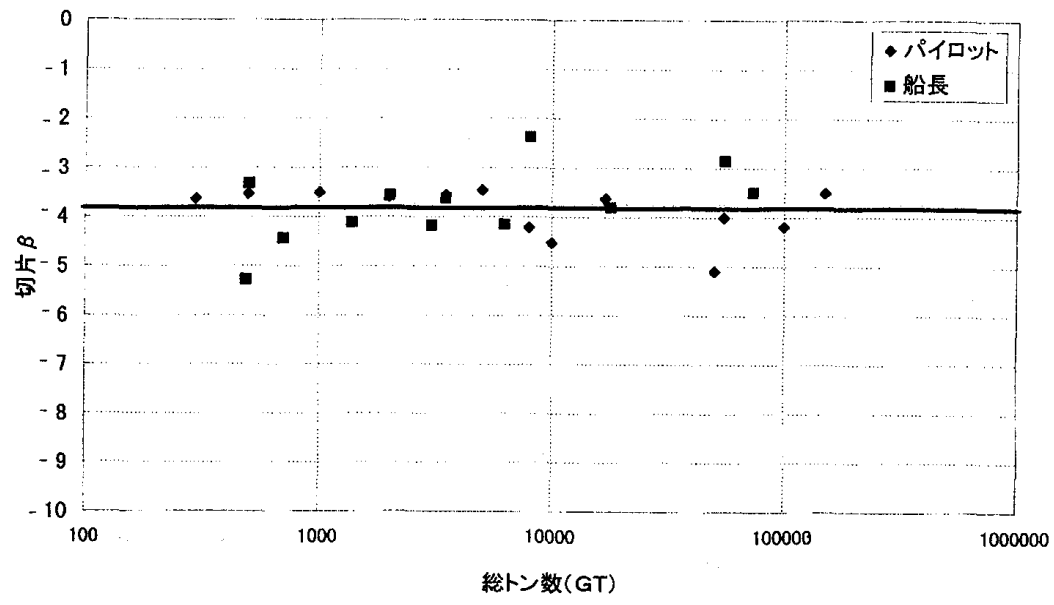

図4 自船船型と切片 $(\beta)$ の関係 (水先人、船長) 
差はないといえる。したがって、操船者の意識をモデル化するにあたっては、シミュレータ実験とアンケ 一ト調查の両データを総合して解析を行うことにする。

また、図2、図 3、図4のそれぞれのプロット傾向に着目すると、以下のような特徴を見いだすことが できる。

(1)それぞれの自船船型ごとに求めた回帰直線は、自船船型が大きくなるにしたがってその勾配が小さく なる。

(2)水先人に関して得られた回帰直線の勾配と船長に関して得られた回帰直線の勾配とは、自船船型に応

じて変化する傾向はともに同様の変化傾向を示すが、両者の間には差が認められる。

(3)回㷌分析により求められた回帰直線の切片は船型には依存しない。また、水先人と船長とではほぼ同 じ值をとる。

ここに、(1)において、船型が大きくなるにつれて勾配が小さくなることは、すなわち、危険が顕在化す るまでの余裕時間が同じであれば自船船型の大きい方がより大きな危険を感じることを意味する。また、 (2)において、自船船型が同じ条件でも水先人よりも船長の方が小さな勾配の值をとることは、すなわち、 危険が顕在化するまでの余裕時間が同じでも船長の方がより大きな危険感を感じることを意味している。

このように、水先人と船長の場合では、勾配の值に明らかに差があることがわかったため、ここでは、 水先人と船長のそれぞれの危険感の違いを反映させることのできる定量化モデルの策定を図ることとした。

なお、護岸への乗り揚げの危険が顕在化するまでの時間余裕 $(R / V)$ を操船者の危険感 $(S J L)$ に置き換え るための変換式のモデル表現にあたっては、すでに述べたように、以下に示す式を基本とし、勾配 $(\alpha)$ と 切片 $(\beta)$ を自船船型の関数として整理する。

$$
S J L=\alpha(R / V)+\beta
$$

図 2〜図 4のプロット図をもとにすると、以下のように、操船者の危険感に関する定量化モデルが得ら 机る。

水先人に関しては、

$$
\begin{array}{rlrl}
S J L & =\alpha(R / V)+\beta & & \\
\alpha & =-0.00092 \cdot \log _{10}(G T)+0.0131 \quad: & G T \leqq 10,000 G T \\
\alpha & =0.010103 \cdot \exp \left\{-7 \times 10^{-6}(G T)\right\} \quad: & G T>10,000 G T \\
\beta & =-3.82 & &
\end{array}
$$

船長に関しては、

$$
\begin{array}{rlrl}
S J L & =\alpha(R / V)+\beta & & \\
\alpha & =-0.00092 \cdot \log _{10}(G T)+0.0099 \quad: & G T \leqq 10,000 G T \\
\alpha & =0.006671 \cdot \exp \left\{-7 \times 10^{-6}(G T)\right\} \quad: \quad & G T>10,000 G T \\
\beta & =-3.82 & &
\end{array}
$$

\section{3. 他船との接近に対する危険感の抽出}

\section{1 アンケート調査の実施}

港内での操船は、開けた水域の場合と異なり、操船水域が防波堤や護岸などの障害物で制約される。こ こでは、このような制約水域を航行するときの、他船との出会いと接近に伴う操船者の危険感を抽出し、 定量化する。

操船者の意識の中に存在するこのような危険感の抽出にあたっては、操船シミュレータ実験とアンケー 卜調査のいずれの調査方法においても、抽出されたデータには互いに補完対応関係にあることが認められ たため、大量のデータを得ることができるアンタート調查の方法を採用した。

アンケートは、水先人向けと船長向けに作成し、SJLに関するアンケートと同時に郵送により配布した。 回答にあたっては、回答者は港内を航行するときの自船速力を想定して記入したうえで、港内で自船と ほぼ同速力の他船と出会うものとして、衝突関係にある他船に一定速力で接近し続ける際に、他船との接 近距離に応じて感じる危険感を直感的に答えるものとした。

なお、港内で他船と出会うときの見合い関係は、右舷からの横切りで交差角が45度、90度、135度の場合、 
左舷からの横切りで交差角が45度、90度、135度の場 合、船首からのエンドオンの行き会い、そして、自 船が真後ろから他船に追い付く場合の8ケースを設 定した。

水先人用のアンケート調查においては、SJLのアン ケートと同様、回答にあたり自分が操船する船は、 300GT、1,000GT、5,000GT、10,000GT、17,000GT、 50,000GT、100,000GT、150,000GTの 8 種類の船型 とした。そして、水先人用のアンケートでは、港内において自船と同じ大きさの他船と出会うものとした。

一方、船長用アンケートにおいては、回答にあたり自分が操船する船は各自が設定する方式をとった。 回答者が想定した船型は、SJLアンケートの時と同様、そのグループ分類は、300〜600GT、600 800GT、 800 2,000GT、2,000 4,000GT、4,000 10,000GT、10,000 30,000GT、30,000GT以上の 7 種類とし

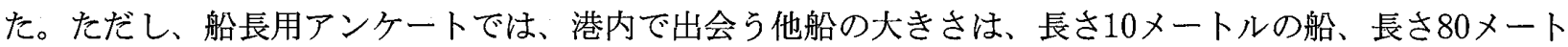

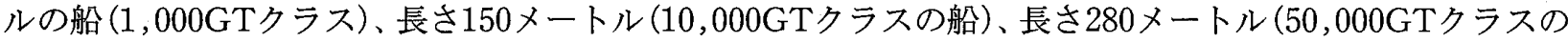
船)の 4 種類に設定した。

配布したアンケート用紙の部数と回収されたアンケート用紙の部数は、表 2 にとりまとめたとおりであ る。ここに、有効回答数として示しているものは、各設問の記入事項に記入漏れや誤解等による不適切な 記入があってデータとして取り扱うことができないものを除外した件数である。

\section{2 危険感に関する回答の集計}

水先人が想定した港内速力は、2 13ノットの範囲にばらついていたが、とくに 6 ノットから 8 ノット の範囲には多くの想定速力が集中していた。そこで、ここでは、6ノットから 8 ノットの速力の範囲を分 析のための原データとした。なお、これらの速力範囲には全体の約 $75 \%$ の回答が含まれる。

一方、船長が想定した港内速力は 1 ～14ノットの範囲にばらついていたが、とくに4ノットから10ノッ トの範囲に多くの想定速力が集中していた。そこで、船長の回答の集計に際しては、4ノットから10ノッ トの速力の範囲を分析のための原データとした。なお、これらの速力範囲には全体の約 $75 \%$ の回答が含ま れる。

他船との相対距離 $(R)$ とそのときに感じる危険感に関する原データの散布図を見ると、水先人の回答につ いても船長の回答についても、いずれも SJLに関するアンケートの場合と類似のデータ散布の傾向が見られ た。

他船と出会うときに操船者が感じる危険感を定量化したこれまでの研究例として、自船から見た相手船 との相対距離および相対方位の変化率に着目し、両船の見合い関係ごとに、方位変化率の大きさと相手船 との相対距離に応じた危険感を主観的な評価值として表現した原 ${ }^{(4)}$ の研究がある。ここで行ったアンケート は、他船と衝突することを前提にしているので、このアンケート調査から得られる操船者の危険感は、原 の研究の特別な場合に相当すると考えられる。

原の研究によると、操船者が感じる危険感は自他船間の相対距離と自他船の船の長さの平均值で基準化 して整理できるとしている。ここでは、この考えにしたがい、各々の出会い条件ごと、自船速力ごと、お よび、自他船の大きさの各々の組み合わせごとに求めた原データにおいて、自他船間の相対距離 $(R)$ を自他 船平均船長 $(L m)$ で除して、操船者が感じる危険感 $(S J S)$ を整理した。

水先人および船長の回答とも、自他船間の相対距離 $(R)$ を自他船平均船長 $(L m)$ で基準化した後のデータ の分布はよくまとまっており、大きなばらつきはみられなかったので、各々の出会い条件ごと、自他船の 大きさの組み合わせごとに、それぞれの自船速力範囲のデータを合算して集計することとした。

各々の出会い条件ごとに求めた解析対象データをみると、基準化された両船間の相対距離と操船者が感 じる危険感の間には直線近似の可能性が予想された。しかし、回帰直線の勾配の大きさは自他船の大きさ の組み合わせに応じて変化する。そこで、回帰直線の勾配 $(\alpha)$ と縦軸切片 $(\beta)$ を自他船平均船長に応じて 変化するパラメータ」として、出会いの条件ごとに、

$$
S J S=\alpha(R / L m)+\beta
$$

$\alpha=f($ 自他船平均船長 $)$ 
$\beta=f($ 自他船平均船長)

SJS : 他船との接近に対して操船者が 感じる危険感

$R:$ 他船との相対距離二衝突までの 余裕時間 $\times$ 相対速力

$L m:$ 自他船平均船長

の形のモデル式を策定することとした。したがって、 $\alpha$ と $\beta$ の值を自他船平均船長の関数として整理する ことにより、与えられた出会い条件下において他船 との衝突の危険が顕在化するまでの時間余裕を操船 者が感じる危険感に置き換えるための変換式を得る ことができる。

\section{3 回㷌分析}

アンケート調査の解析にあたっては、 $\left(R^{\prime}=R / L m\right)$ を説明変数、抽出した危険感 $(S J S)$ を目的変数とした 直線近似による回帰分析を行った。水先人のデータ に関する回帰分析の結果も船長のデータに関する回 帰分析の結果む、いずれもおおむね 関係数が得られた。

3.4 他船との接近に対し操船者が感じる危険感の 定量化モデルの策定

図 5 、図 6 は、自船の右舷側から他船が横切る場 合について、水先人と船長に関する回帰分析の結果 から得られた勾配 $(\alpha)$ の值を自他船平均船長 $(L m)$ を 横軸にとってプロットしたものである。図 5 は水先 人のデータに関するプロット、図 6 は船長のデータ に関するプロットである。各プロットはよくまとま っておうり、横切りに掠ける交差角の違いによる差は みられない。

また、図7、図8は、自船の右舷側から他船が横 切る場合について、水先人と船長関する回帰分析 の結果から得られた切片 $(\beta)$ の值を自他船平均船長 $(\mathrm{Lm})$ を横軸にとってプロットしたものである。図7 は水先人のデータに関するプロット、図 8 は船長の データに関するプロットである。このほかにも、自 船の左舷側から他船が横切る場合、正面から他船と 行き会う場合、自船が他船を追い越す場合のプロッ トがあるが図面掲載は割愛する。

水先人に関する回帰分析加ら得られた勾配 $(\alpha)$ と 切片 $(\beta)$ 就よび船長に関する回帰分析から得られた 勾配 $(\alpha)$ と切片 $(\beta)$ のプロット結果より、以下のよ うな特徴を見いだすことができる。

(1)回帰分析により求められた回帰直線の勾配の值 が自他船の平均船長に応じて変化する様子は、 水先人、船長を問わず共通の傾向を示す。また、 これらはすべての出会い条件において共通の変 化傾向を示す。

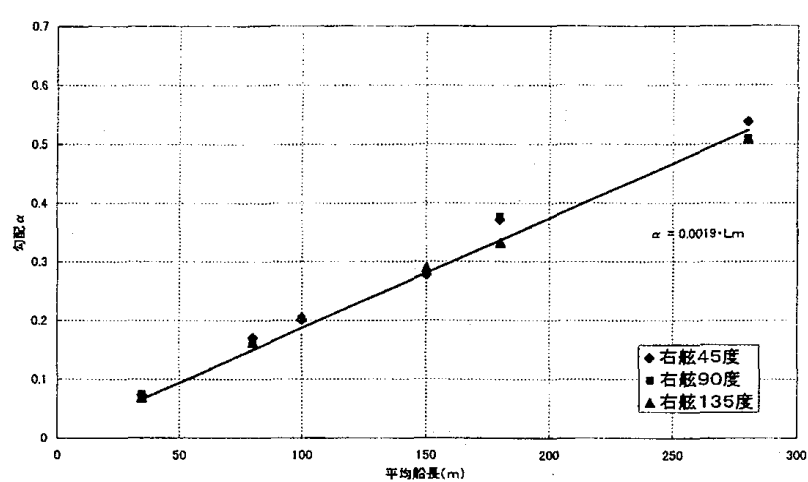

図 5 自他船平均船長と勾配 $(\alpha)$ の関係 (水先人、右舲加らの横切り)

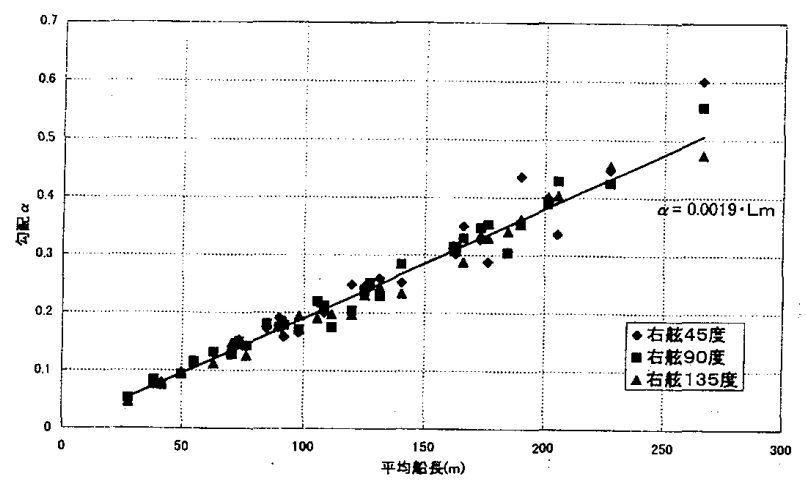

図 6 自他船平均船長と勾配 $(\alpha)$ の関係 （船長、右舷からの横切り）

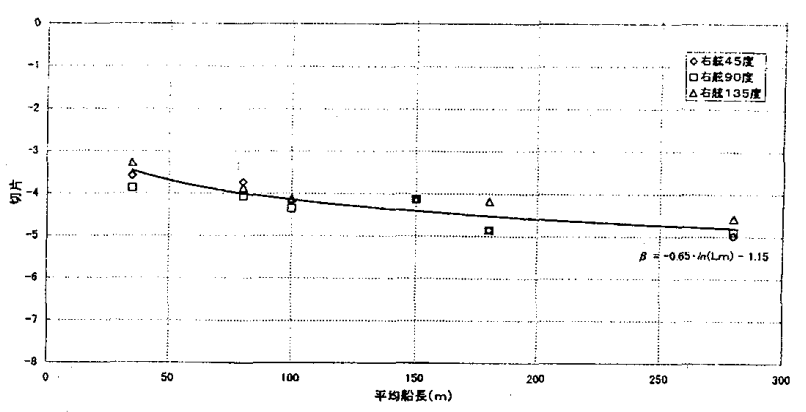

図 7 自他船平均船長と切片 $(\beta)$ の関倸 (水先人、右舷からの横切り)

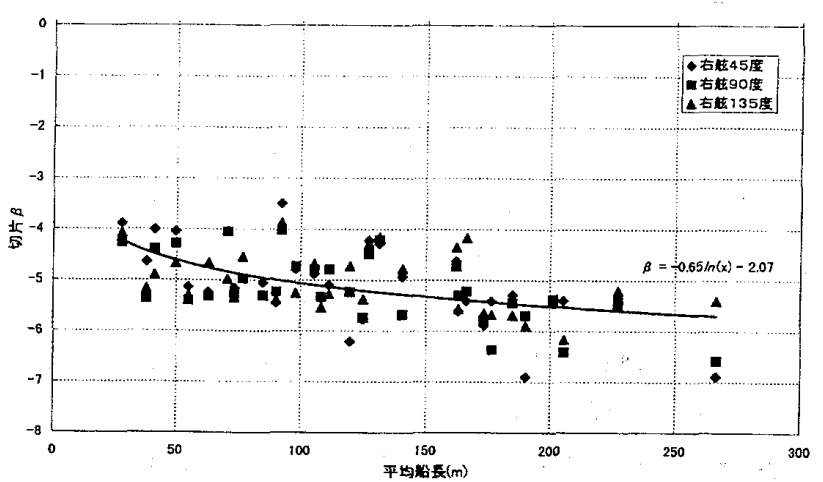

図 8 自他船平均船長と切片 $(\beta)$ の関係 (船長、右舷力らの横切り) 
(2)ただし、図 7 と図 8 を比較してもわかるように、切片の值々船長に関するプロットの方が全体に下側 に位置する。このことは、同じ水域、同じ自他船の組み合わせ、同じ見合い関係、同じ相対距離でも、 水先人よりも船長のほうがより強く危険を感じることを意味している。これは、水先人は操船経験が 豊富で狭い水域空間での船との出会いに慣れているのに対し、船長は狭い水域空間での操船に慣れて いないことなどが考えられる。つまり、船長と水先人とでは危険の感じ方に違いがあるといえる。

(3)全体に自他船の大きさの組み合わせが大きくなるほど切片の值が小さくなる傾向がみられる。このこ とは、同じ水域、同じ相対距離でも自船が大きかったり出会う他船が大きい場合は操船者が感じる危 険感が増すことを意味している。

(4)このほか、出会い条件に関しては、右からの横切りに対する危険感よりも、左からの横切りに対する 危険感の方が高く、そして、相手船を右に見る横切り関係の場合と正面から行き会う場合とは危険感 はほぼ同等であるといら結果が得られた。

すでに述べたように、他船との衝突の危険が顕在化するまでの時間余裕を操船者の危険感に置き換える ための変換式のモデル表現にあたっては、以下に示す式により整理し、そして、勾配 $(\alpha)$ と切片 $(\beta)$ の值 は自他船平均船長の関数として整理することとする。

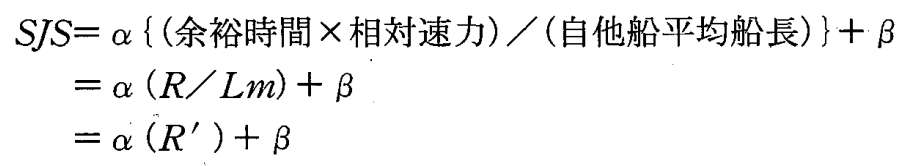

図 5 〜図 8 のプロット図をもとにすると、以下のように、操船者の危険感に関する定量化モデルが得ら れる。

勾配 $\alpha$ にいては、

水先人、船長とも全見合い関係について

$\alpha=0.0019 \cdot \mathrm{Lm}$

ただし、 $L m$ ：自船船長と他船船長の相加平均

切片 $\beta$ につては

水先人の危険感

右舷からの横切りの場合 $\quad: \beta=-0.65 \cdot \ln (L m)-1.15$

左舷からの横切りの場合 $\quad: \beta=-0.65 \cdot \ln (L m)-1.35$

船首からの行き会いの場合 $\quad: \beta=-0.65 \cdot \ln (L m)-1.15$

真後ろから自船が追い越す場合 : $\beta=-0.65 \cdot \ln (L m)-0.1$

船長の危険感、

右舷からの横切りの場合 $\quad: \beta=-0.65 \cdot \ln (L m)-2.07$

左舷からの横切りの場合 $\quad: \beta=-0.65 \cdot \ln (L m)-2.35$

船首からの行き会いの場合 $\quad: \beta=-0.65 \cdot \ln (L m)-2.07$

真後ろから自船が追い越す場合： $\beta=-0.65 \cdot \ln (L m)-0.85$

\section{4. 危険感の定量化モデルに関するさらなる知見}

\section{1 従来の研究との比較}

護岸に接近する過程で操船者が感じる危険感の抽出については、原・田中 ${ }^{(3)}$ が外航船々長を被験者として 操船シミュレータ実験を実施した経緯がある。このとき得られたデータも本研究と同様に直線回帰分析が なされているので、回帰直線の勾配 $(\alpha)$ と切片 $(\beta)$ を比較することによって、両者の対応関係は吟味でき る。図 9 に、本研究においてモデル化した船長の危険感に関する結果と原・田中の実験結果との比較を示 す。切片の值については両方の結果にほとんど差がみられなかったので、図 9 には回帰直線の勾配につい てのみ対応関係を示している。

本研究において策定したモデルでは、自船船型の大きさに応じて勾配の值が異なる傾向が明らかになっ た。しかし、原・田中の実験は、対象とした船型の範团の結果からみるかぎりは勾配の值は自船船型に無 関係に一定の值をとるように見える。勾配の値の大きさについては、原・田中の実駼結果は本研究の結果 
よりも大きな值をとり、危険感が和らぐ方向の結果を与えている。これは原・田中の害験では開けた広い 水域を想定しているのに対し、本研究では港内などの制約水域を想定して実験を行ったことより、水域環 境が異なることで操船者の感じる危険感に違いが現れたと考えられる。

次に、他船と出会うときに操船者が感じる危険感の抽出に関しては、原 ${ }^{(4)}$ の研究がある。この研究では、 両船の見合い関係ごとに、方位変化率の大きさと相 手船との相対距離に応じた危険感を主観的な評価值 として表現している。この評価值においては自船と 他船が衝突関係にあるときは方位変化率がゼロとな り、操船者が感じる危険感は自他船間の相対距離の みの関数になる。

図10は、他船と右から横切り関係で出会い、その 後衝突に至る過程で両船の接近に応じて操船者が感 じる危険感を、両船間の相対距離を自他船の平均船 長で基準化した值 $\left(R^{\prime}\right)$ を横軸にとって、両モデルに ついて比較したものである。

図中、太線は原のモデルによる結果を、細線群は 本モデルによる結果を示している。原の、モデルで はすべての自他船の大きさの組み合わせに対して共 通した危険感を与えるのに対し、本モデルにおいて は、大きい船同士、小さい船同士、大きい船と小さ い船といったように出会う自他船の大きさの組み合 わせの広い範囲に対応する危険感の表現が可能とな っている。

\section{2 危険感と許容感の関係}

護岸への接近に応じて操船者が感じる危険感とそ のときの危険感を許容するかどうか、つまり、危険 感と許容感とは異なる意識と考えられる。そこで、 護岸接近に伴う危険感抽出の際に実施した操船シミ ユレータ実験の最後に、各被験者に対し、危険感の どのレベルに達すると操船者としてその状態を許容 できなくなるかについて統一した用紙を用いて回答 を求めた。

このアンケートでは、 -3 (非常に危険)、 -2 (か なり危険)、 -1 (やや危険)、0 (どちらとむいえな い)のそれぞれの危険感のレベルに対し、十分許容で きる、許容の限界に近いがまだ許容できる、許容の 限界または限界を越えている、許容できない、のう ちから最む近い感覚をひとつを選択回答する方式と した。

図11は、このようにして得られた回答からそれぞ れの危険感に刘する許容可能々許容不可能の回答比 率を整理したものである。水先人 10 名、外航船長 9 名、内航船長 11 名のグループ間に回答比率の差はな く、それぞれ共通の許容感を有することが分かった。 これより、ー-2(かなり危険)、一 -3 (非常に危険)の 危険感については全体の 8 割以上が許容できない状 態にあり、 -1 (やや危険)の危険感については全体

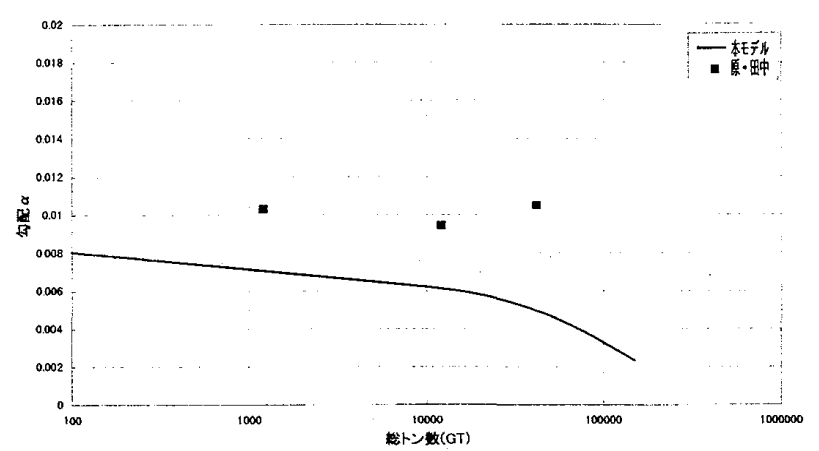

図 9 本モデルと原・田中の実験結果の比較

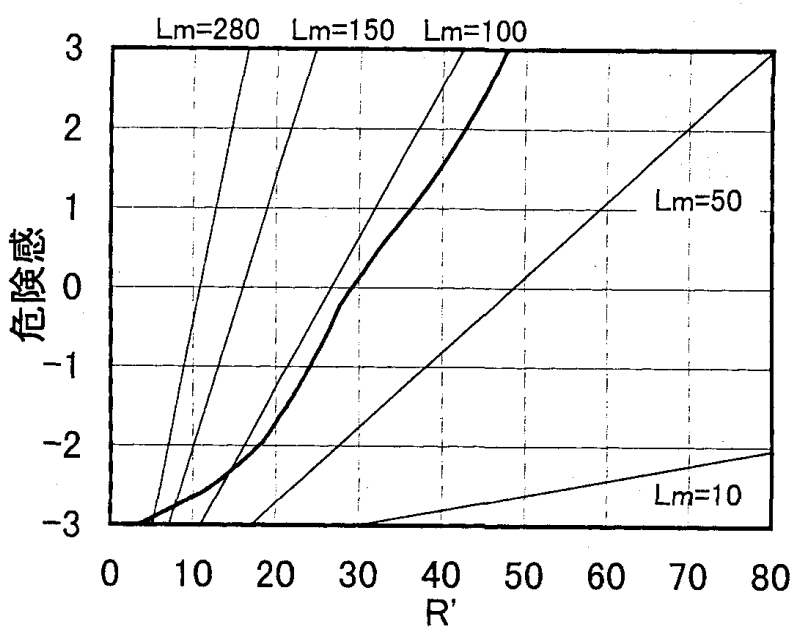

図10 本モデルと原のモデルの比較

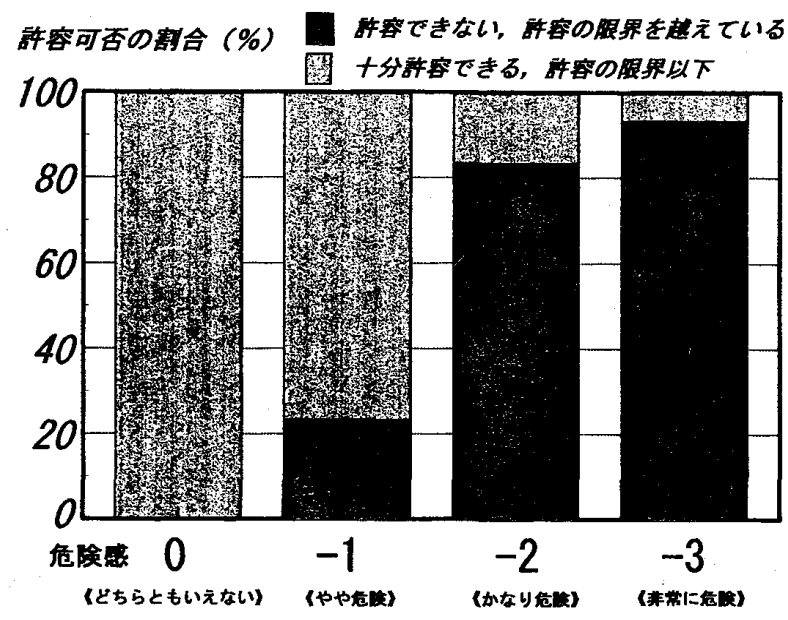

図11 危険感に対する許容可否の感覚 
の 2 割が許容できない状態にあることがわかった。

\section{3 操船者意識の個人差の考慮}

多くの操船者集団の中には、大胆な操船者、慎重 な操船者など、安全に対し様々な感覚を持つ操船者 がいるものと考えられる。本論文では、第 2 章、第 3 章に述べたようにデータの分布に対し直線回帰を 行うことにより、標準的な操船者の意識をモデル化 した。ここでは、このような標準的な操船者の意識 に対して、危険に対して大胆な操船者、抒よび安全 に対し慎重な操船者の意識の違いを表現することを 試みた。

同じ危険顕在化までの余裕時間に対してもより強

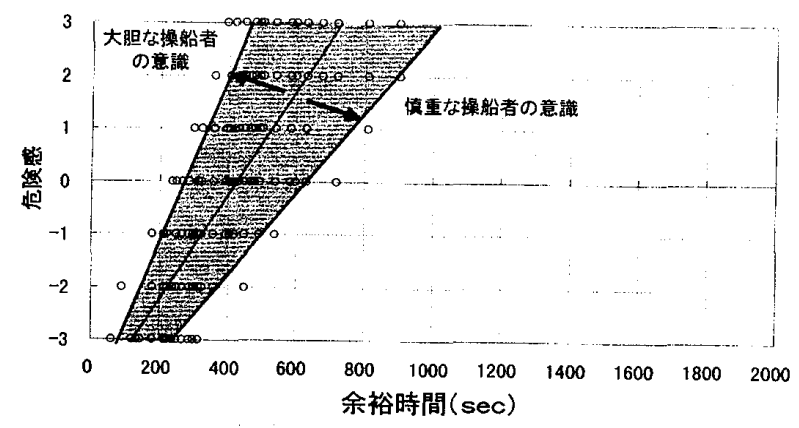

図12＼cjkstart操船者意識の個人差の考慮

く危険を感じる操船者の意識を代表させる、または、あまり危険を感じないとする意識を代表させるため には、勾配 $(\alpha)$ の值を変化させることが考えられる。この手法では、危険顕在化までの余裕時間が大きく なるほど意識の格差はより大きくなって現れる。たしかにデータの分布状況をみると、余裕時間の増加に 伴ってデータは扇形に広がっている様子が見える。そこで、本研究では、勾配 $(\alpha)$ に変化を与えることで 大胆な操船者の意識、慎重な操船者の意識を表現することを試みた。

具体的には、図12に模式図を示すように、標準的な操船者の意識をモデル化した回帰式の勾配 $(\alpha)$ の值 を基準として、この $\alpha$ の值に一定の係数を乗じた。 $\alpha$ により大きい值の係数を乗じることは勾配が急峻 になるので大胆な操船者の意識を表現することになり、 $\alpha$ により小さい係数を乗じることは勾配が緩や かになるので慎重な操船者の意識を表現することになる。

このような考えのもと、護岸への接近に関する危険感を表現するモデル式については、係数を 1.5 おび 0.5 とするとき、また、他船との接近に関する危険感を表現するモデル式については、係数を 1.4 おび 0.6 とするとき、これらの係数を乗じた式の範囲内にはおよそ全データの 8 割強を含むことになる。このこと は 5 人の操船者がいればその内の 4 人の操船者の意識が含まれていることになる。

この範囲でカバーできなかったデータは、過度に大胆な意識、過度に慎重な意識と考えることもできる ので、本研究では上記の係数を用いて危険に対して大胆な操船者の意識、安全に対して慎重な操船者の意 識を表現することとした。

\section{5. むすび}

操船者を取り巻く周辺環境は著しく変化し、とくに近年、湾内や狭水道での海上交通ならびに港湾の出 入操船の安全を確保するためには、操船者の安全や危険に関する意識に基ゔく評価が重要になってきてい る。

本研究では、護岸への接近に対して感じる危険感と他船への接近に対して感じる危険感とを表現できる 定量化モデルの策定を目的として、操船シミュレータによる実験とアンケート調查を実施した。その結果、 多くの操船者の意識を代表できる実用モデルを策定することができた。

その過程で、船長と水先人とでは危険に対する感じ方に違いがあることがわかり、これらの意識の違い を反映するモデルの策定を試みるとともに、また、危険の感じ方に関する個人差についても考慮し、危険 に対し大胆な操船者、安全に対し慎重な操船者の意識も表現するようモデルに工夫を加えた。

\section{参 考 文 献}

（1）井上ほか：操船者の危険感に基づく操船環境の評価一評価指標としての環境ストレス值の定義一，日 本航海学会論文集, 第95号, 平成 8 年 9 月.

（2）井上ほか：操船者の危険感に基づく操船環境と交通環境の同時評価法, 日本航海学会論文集, 第97号, 平成 9 年 9 月.

（3）原・田中：コースラインの自動設定に関する研究，日本航海学会論文集，第 96 号，平成 9 年 3 月. 
（4）原：輻輳海域における避航操船基準の有効性，日本航海学会論文集，第85号，平成 3 年 9 月.

\section{質 疑 応 答}

村山義夫 (海上労働研究所)：危険感とは情動反応を含む心理反応と考えられる。一般に刺激一反応は指数 関数的関係になり、反応しきい值がある。本結果は両関係を直線回帰していること、直近まで反応がり ニアにあることから心理量を示すより、距離認知の反応と考えられないだろらか、これらの点について 見解をらかがいたい。

久保野雅敬：本研究では、障害物との接近距離に対して操船者が感じる危険感を表現することを試みてい ます。危険感は 0 を中心に士 3 の範囲の離散数值で回答を求めました。その結果、障害物までの距離が

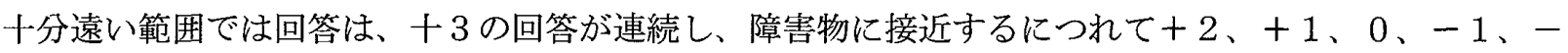
2 と変化し、そして、障害物までの距離が十分近い範囲になるとー 3 の回答が連続するようになるのが 一般的でした。これからわかるように、あるしきい值以内の至近距離についての回答は連続したー 3 に 含まれています。したがって、この部分に指数関数関係が含まれているものと思います。

なお、データの分析に際しては、一連の連続したデータのらち、最後の+ 3 から最初のー 3 までのデ 一タ群を対象に回帰分析することとしました。したがって、この結果からは指数関数関係は表に現れま せ九。

遠藤 真(富山商船高等専門学校)：アンケートのみで構築されたモデルですが、アンケート結果と実務の 操船結果とが対応する保証はあるのですか。このモデルには客観的解析が久けていると考えますが、ご 教示願いします。

久保野雅敬：船を実際に操船する人達の意識の裏には、その人が意識するしないにかかわらず、安全や危 険に対する感覚についてある物理量と一定の定量対応関係が存在しているものと思います。この研究は、 この意識を抽出して定量表現しようとしたものです。そのため操船シミュレータによる実験とアンケー 卜調查による方法を併用しました。実船を模擬した操船シミュレータを使用してその画面に映し出され る動く映像をみながら実際に近い状況下で障害物接近に対する危険感を抽出した結果とアンケートによ り想像の世界から危険感を抽出した結果とは良い対応関係を示しました。このように異なる意識抽出の 手法によっても両者が相補完する関係が見いだされたということは、まさに操船者の意識の裏に存在す る定量的対応関係の抽出に成功したものといえます。したがって、実船実験こそ行っていませんが、そ れを行っても同様の意識が抽出されるものと考えています。もちろん実際の船で実験するのも手ですが、 実現性、所要時間、費用、労力の面で問題があり、特に被験者数が限られるのが最も難点です。この種 の研究で重要な課題はできるだけ多くの操船者の意識を代表するモデルの構築です。そして、主観的で なく客観的な解析ができたかどうかは、ひとりひとりの操船者がもつ主観感覚をできるだけ多くの人々 の意識をもとに普遍的に表現できたかどうかです。このような「主観の客観化の問題」を扱うときに数人 の意見の結果のみを扱うときは、“それは一部の人の主観を解析したものであって客観的解析に欠ける” といわれても仕方がないと思います。しかし、この研究のように数百人の回答を整理して得られるモデ ルには普遍性が伴っていると判断され、「主観の客観化」は成し遂げられたといっても良いと思います。 